\title{
Birds species composition and abundance of a relativelly undisturbed vegetation at Mount Pati, Lokoja, Kogi State
}

\section{Dauda Tanko* and Rita Chinweuba}

Department of Biological Sciences, Federal University Lokoja, Kogi State. *Email: tyankwa2007@yahoo.com.

\begin{abstract}
Avifauna of a relatively undisturbed vegetation at Mount Patti of Lokoja was surveyed from January to June, 2018. Line transect and point count techniques were used for data collection. This was done by weekly visits to the site between 6:00 $\mathrm{h}$ and 10:00 $\mathrm{h}$ of the day. Bird identification was done with the aid of a pair of binoculars, Field Guide of birds of western Africa and recorded bird calls. Monthly variation and season variation in bird composition and abundance were compared using Shannon-Wiener diversity index and equitability index. There were 39 species in 21 families encountered during the survey. The Family Nectarinidae had the highest number of 5 species, followed by Columbidae and Estrildidae with 4 species each. A total of 1,148 individuals were encountered during the six months survey with village weaver having the highest encountered rate of 107 while yellow-throated Long-claw had the least encountered rate of 4 individuals. Fluctuation was observed in the monthly encountered rate of the birds. Diversity and equitability indices had their highest values of 5.24 and 1.51 in January. More birds (696) were encountered in the wet season than the dry season (452). Four species were seen only in the wet season. Species effort curve showed that there are more species to be discover. The number of species encountered in this study revealed that the mountain is rich composition of bird species, even though the site seems to favour species that show preference to disturbed areas. The on-going anthropogenic activities probably paved way to these species to move in. Monthly and seasonal fluctuation of bird species diversity and abundance may be due to a combination of physical and biological factors. The physical and biological factors observed at the site which we speculate could be reasons for the observed fluctuations include slash and burnt system of farming, fuelwood harvesting, intensive sporting activities creation of foot paths etc. High encountered rate indicate abundance and high activity level of the species. The village weaver was the most encountered species probably because they are known to be lousy, move in flocks and breed in colonies. In view of the rich composition and abundance of bird species on Mount Patti and the site being a suitable breeding site for the weavers. We recommend further study of the place as there are yet more
\end{abstract}

Received

January 21, 2019

Accepted

March 23, 2019

Released

April 30, 2019

Full Text Article

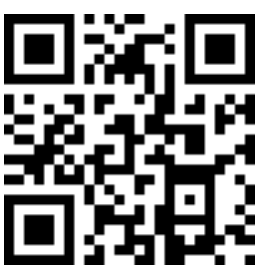

ORCID

(1) 0000-0001-6745-2333 Dauda Tanko

(1) 0000-0001-5343-7140 Rita Chinweuba 
species to be discovered as indicated by the species effort curve. There is need for conservation procedures to be initiated at the place and this study should serve as a baseline to initiate such programme by the state government.

Keywords: Avifauna; Undisturbed vegetation; Mount Patti; Composition; Abundance.

\section{Introduction}

Birds forms a very important group of organisms, inhabiting almost everywhere on earth and serving the role of indicators of environmental health and conditions. Therefore, an environment that is healthy will witness a very abundant bird species as well as other organisms (Adang et al., 2015). Birds serve as pointers to universal biodiversity and one of the reasons is their ability to occupy almost every terrestrial, aquatic and mountainous zones (Birdlife International, 2000). Bibby et al. (2000) pointed out that birds are very easy to notice, serving various important functions, mostly as biological tools for education. The dispersal of seed is among the vital roles birds play in the ecosystem. Because birds are always on the move, seed dispersal by them is geographically widespread, thus, both the birds and the plants are taxonomically diverse. Bascompte and Jordano (2007) are of the opinion that plant and their avian dispersers form part of a complex mutuality network that is fundamental to maintaining biodiversity and community structure. Plants benefits in several ways like gene flow (Godoy and Jordano, 2001), escape from areas of high mortality (Harms et al., 2000), colonization of new sites (Shanahan et al., 2001), and direct dispersal to sites (Wenny and Levey, 1998). These and some other importance of avian seed dispersal contributes to the restoration and recovery of degraded lands (Lozada et al., 2007). Another important role bird species play in the ecosystem is cleaning of the ecosystem as scavengers. For instance, birds like the pied crow Corvus albus, through their scavenging activities contributes to the biomass recycling and to a large extent reduce the level of disposable wastes within the ecosystem (Judd et al., 2008). Studies have shown that the removal of carcass by scavengers is faster as compared to other means (DeVault et al., 2004). This was evident in the increased presence of rats and feral frogs in India when the Indian white-backed vulture Gyps bengalensis, long-billed vulture Gyps indicus, and slender-billed vulture $G$. tenuirostris reduced in population, leading to the accumulation of putrefying carcasses (Pain et al., 2003).

In the tropical regions, the mountains have been found to have very high composition of bird species and in association with other species within the habitat (Jankowski et al., 2009). The mountains notably support about $75 \%$ of birds' species and $45 \%$ of adapted habitat that have been modified by human activities (Birdlife International, 2008). Even though mountains have been found to have a high diversity of species, anthropogenic activities like lumbering, farming, etc., have been negatively affecting the natural habitat of birds' species, influencing their variety and variability (Benes et al., 2003). Though human activities have allowed the expansion of a few species of birds such as the barn swallows and the European starling, they have in no small way contributed to the decline or extinction of some other species (Fuller, 2000). The disturbances or total destruction of bird's habitat have been observed to be on the increase in recent times (Manhães and Ribeiro, 2005).

Most bird species are particular about their choice of habitat, and are influenced by various ecological 
characteristics when it comes to chosen their habitat. They make preferential selection of vegetation, environmental characteristics and ecosystems. Therefore, any form of alteration on their chosen habitat may leads to their disappearance (Birdlife International, 2000). Composition, diversity and distribution of birds vary along the landscape because they are greatly influenced by variety of factors which may include habitat, topography, anthropogenic activities, climate, etc. (Jankowski et al., 2009). Tanko (2012) observed that continued reduction of habitat can lead to the disappearance of some local species mostly because their source of food has been disrupted. Some bird species feeds primarily on insects and hence are found inhabiting the ground especially during nesting, some other species feeds on aquatic organisms and so are often seen around water bodies. Therefore, these habitat factors limit their distribution and abundance. Tewes et al. (2004) observed that the arrangement of plant communities especially the vertical distribution of foliage influence the distribution and composition of birds more than the composition of plant species. Seasons also play a major role in the composition and abundance of birds as they have great effect on the foods and cover availability of birds, their breeding and finally their survival (Mengesha and Bakele, 2008). Also, the seasonal differences in the amount and duration of rainfall and temperature have effects on these birds and these may result in the alteration in the diversity, abundance and distribution of birds of an area. Though some birds are generalists and may utilize several habitats, Buckley and Freckleton (2010) noted that the differences in requirements among birds have led to specificity on habitat needs. For instance, the mountain plover Charadrius mountainus that feeds primarily on insects usually utilize the ground for nesting and have a preference for short grass while the Mongolian sand plover Charadrius atrifrons that feeds on invertebrates like worms, molluscs and insects like to use the tree for nesting and have preference for shore of the lake.

The pattern in the composition and abundance of bird species is vital to preservation and conservation of nature and therefore the need for studying birds as well as factors that affects their composition and abundance (Bibby et al., 1992). To many, mountains and inselbergs are seen as waste lands and as result are often neglected in terms of research. However, Tanko (2012) opined that they could serve as either source or sink to the threatened species. This aspect of source-sink importance have not been investigated at Mount Patti. To the best of our ability the only existing literatures in avifauna of the Lokoja area is the work of Tanko et al. (2017) and Adang et al. (20018) where they recommended an extensive study of the Mount Patti.

It is on this background that this study was designed to document species of the study area. This study will create the medium for understanding the composition and abundance of birds' species; and provide the baseline data for future referencing and serve as guide in the event of designing conservation and management strategies of the place.

\section{Materials and methods}

\section{The study area}

The study was carried out at mount Patti in Kogi State located in the Northern Central Nigeria. It is a flattopped rocky terrain of about fifteen square kilometres and about 1,500 feet above the sea level (403 meters high). The mountain is located on latitude $7^{\circ}$ 49'16.5” $\mathrm{N}$ and Longitude $6^{\circ} 4^{\prime} 10.0^{\prime \prime} \mathrm{E}$. The vegetation is mostly teak Tectona grandis, gmelina Gmelina arborea, Daniella oliveri the famous baobab tree Adansonia digitata and secondary forest of indigenous plants species. Figure 1 is the map of the study area. 


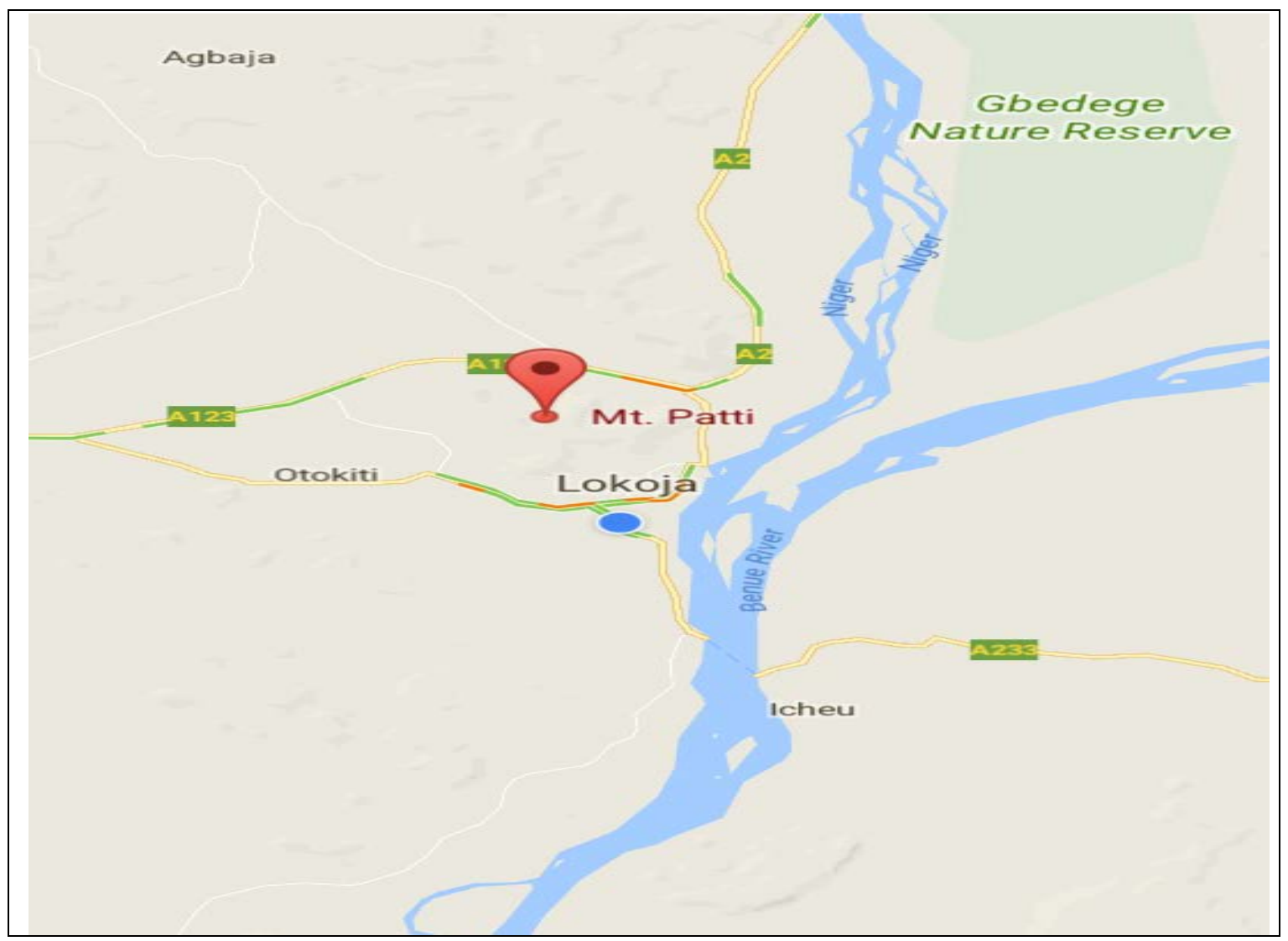

Figure 1. Map of the study area. Source: GIS Lab, KSU (2007).

\section{Method of sampling}

The work was done during the dry (January to March) and rainy seasons (April to June) 2018. Point count and line transact methods described by Gibbons (1996) and Tanko (2012) were used to determine the diversity and abundance of the birds. Fifteen sampling points were predetermined at a distance of $100 \mathrm{~m}$ interval. These points were visited once in a week for sampling. The visits were carried out between $6: 30 \mathrm{~h}$ and 10:00 h in the morning because birds are active during the early hours. On getting to each predetermined point, 2-3 min waiting period were given in order for the birds to settle in case of any disturbance in the cause of entering the place. Then about 5 min were used to count and record all birds seen or heard within $50 \mathrm{~m}$ radius. The identification of birds were done using field guide of birds of Tropical Western Africa, by Borrow and Demey (2004). The unidentified birds or their calls were recorded using a tape recorder for further identification by experts or by comparing with recorded bird calls.

The anthropogenic activities that could affect bird abundance and distribution

The anthropogenic activities were assessed using visual observation. In each of the visits, human related activities such as farming, fuel wood harvesting, debarking, bush burning, hunting, habitat modification and habitat fragmentation were observed. Representative photographs of these activities were taken.

\section{Data analysis}

Shannon Wiener Diversity Index and equitability index were used to compare the birds' abundance between the wet and dry seasons and between the months sampled. 


$$
\text { Diversity index } H^{\prime}=-\sum_{i=1}^{R} P i L n P i
$$

and

$$
\text { Equitability } E=H^{\prime} / \operatorname{LnS}
$$

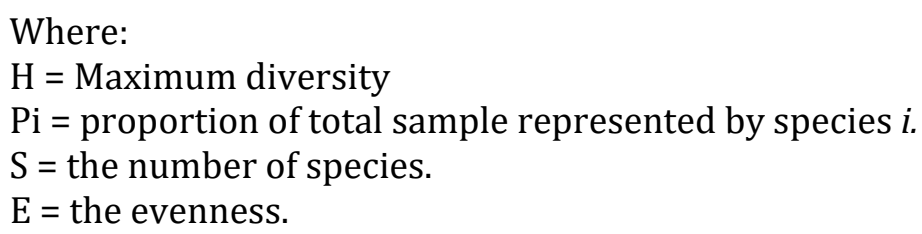

\section{Results}

The study revealed thirty-nine (39) bird species belonging to twentyone (21) families and encounter rate of 1148 individuals. The Family Nectariniidae had the highest number of species of 5 , followed by the families Columbidae and Estrildidae with 4 species each. Two of the 21 families had 3 species each, four others had 2 species each and the remaining 12 families had 1 species each (Table 1). Out of the 39 species encountered, Ploceus melanocephalus (village weaver) had the highest total number of individuals encountered (107) while Macronyx croceus (yellow-throated long-claw) with only 4 individuals encountered was the least (Table 2).

Table 2 is the monthly distribution of the bird species during the study months. The month of April had the highest number of individuals (252), and was followed by the month of June (234), while the month of January had the least number of individuals (137).

Figure 2 is the graphical representation of the seasonal distribution of bird species during the study while Figure 3 is the species effort curve showing the new species recovery per visit. More birds were encountered in the wet season than in the dry season with the wet season having 696 encountered rate while the dry season had 452 encountered rate. Ploceus melanocephalus, Ploceus cucullatus, Macronyx croceus and Chlorocichla flavicolis were present in the wet season but absent in the dry season (Table 3). The month of January recorded the highest diversity of 5.24 while the Month of April had the least diversity of 2.95 . The dry and wet seasons diversities were the same (3.36 and 3.32, respectively).

The Equitability was highest in the month of January (1.51), followed by March with equitability of 0.95 while April with equitability of 0.81 was the least. The seasonal equitabilities were the same with values of 0.94 and 0.91 for the dry and wet season respectively. Three species were seen to be stenotopic to that typical habitat. These were the Stone Partridge (associated with rocky habitats) Green Turaco and Veiolet Turaco (associated with the gallery forest).

Some of the anthropogenic activities at the site include: fuel wood harvest, lumbering, debarking of ethnomedicinal purposes; slash-and-burn system of farming and tourist activities. Figures 3-6 are photographical evidences of some of these activities. 
Table 1. A checklist of bird species composition and abundance of Mount Patti.

\begin{tabular}{|c|c|c|c|c|}
\hline S/no & $\begin{array}{c}\begin{array}{c}\text { Taxonomic } \\
\text { group }\end{array} \\
\end{array}$ & Family & English Name & Scientific Name \\
\hline 1 & Kites & Accipitridae & Yellow-billed kite & Milvus aegyptius \\
\hline 2 & Partridges & Phasianidae & Stone partridge & Ptilopachus petrosus \\
\hline 3 & Doves & Columbidae & Red-eyed dove & Streptopelia semitorquato \\
\hline 4 & Doves & Columbidae & Black-bill wood dove & Turtur abyssinicus \\
\hline 5 & Doves & Columbidae & Mourning dove & Streptopelia decipiens \\
\hline 6 & Doves & Columbidae & Laughing dove & Streptopelia senegalensis \\
\hline 7 & Coucals & Cuculidae & Senegal coucal & Centropus senegalensis \\
\hline 8 & Hornbills & Bucerotidae & African grey hornbill & Tockus nasutus \\
\hline 9 & Barbets & Bucerotidae & Yellow-fronted tinkerbird & Pogoniulus chrysoconus \\
\hline 10 & Barbets & Bucerotidae & Yellow-rumped tinkerbird & Pogoniulus subsulphureus \\
\hline 11 & Bulbuls & Pycnonotidae & Common bulbul & Pycnonotus barbatus \\
\hline 12 & Bulbuls & Pycnonotidae & Yellow-throated leaflove & Chlorocichla flavicolis \\
\hline 13 & Thrushes & Turdidae & African thrush & Turdus pelios \\
\hline 14 & Monarchs & Muscicapidae & African paradise flycatcher & Terpsiphone viridis \\
\hline 15 & Sunbirds & Nectariniidae & Scarlet-chested sunbird & Chalcomitra senegalensis \\
\hline 16 & Sunbirds & Nectariniidae & Copper sunbird & Cinnyris cupreus \\
\hline 17 & Sunbirds & Nectariniidae & Splendid sunbird & Cinnyris coccinigastrus \\
\hline 18 & Sunbirds & Nectariniidae & Grey-headed sunbird & Deleornis axillaris \\
\hline 19 & Sunbirds & Nectariniidae & Variable sunbird & Cinnyris venustus \\
\hline 20 & Orioles & Oriolidae & African golden oriole & Oriolus auratus \\
\hline 21 & Weavers & Ploceidae & Village weavers & Ploceus melanocephalus \\
\hline 22 & Weavers & Ploceidae & Little weaver & Ploceus cucullatus \\
\hline 23 & Warblers & Sylviidae & Grey-backed camaroptera & Camaroptera brachyuran \\
\hline 24 & Bush shrikes & Malaconotidae & Black crowned tchagra & Tchagra senegalus \\
\hline 25 & Crows & Corvidae & Pied crow & Corvus albus \\
\hline 26 & Crows & Corvidae & Piapiac & Ptilostomus \\
\hline 27 & Swallows & Hirundinidae & Black saw-wing & Psalidoprocne pristoptera \\
\hline 28 & Turacos & Musophagidae & Green turaco & Tauraco persa \\
\hline 29 & Turacos & Musophagidae & Violet turaco & Musophaga violacea \\
\hline 30 & Turacos & Musophagidae & Western grey plantain-eater & Crinifer piscator \\
\hline 31 & White-eyes & Zosteropidae & African yellow white eye & Zosterops senegalensis \\
\hline 32 & Estridid finches & Estrildidae & Bronze mannikin & Spermestes cucullata \\
\hline 33 & Estridid finches & Estrildidae & Black-and-white mannikin & Spermestes bicolor \\
\hline 34 & Estridid finches & Estrildidae & Bare-breasted firefinch & Lagonosticta rufopicta \\
\hline 35 & Estridid finches & Estrildidae & Red-cheeked cordon-blue & Uraeginthus bengalus \\
\hline 36 & Wagtails & Motacillidae & Yellow wagtail & Motacilla flava \\
\hline 37 & Longclaws & Motacillidae & Yellow-throated long-claw & Macronyx croceus \\
\hline 38 & Sparrows & Passeridae & Northern grey-headed sparrow & Passer griseus \\
\hline 39 & Indigo birds & Viduidae & Village indigo bird & Vidua chalybeata \\
\hline
\end{tabular}




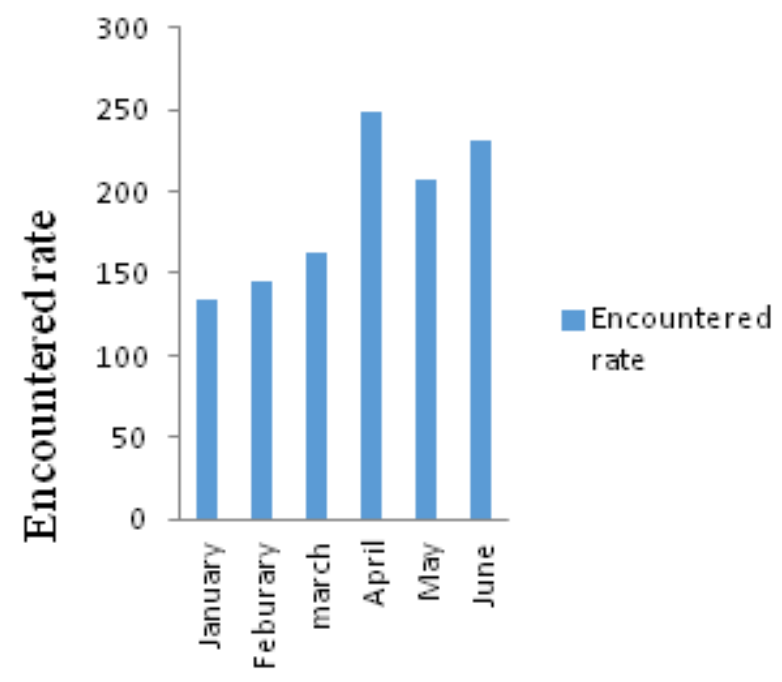

Figure 2. Bird Encountered rate from the months of January to June.

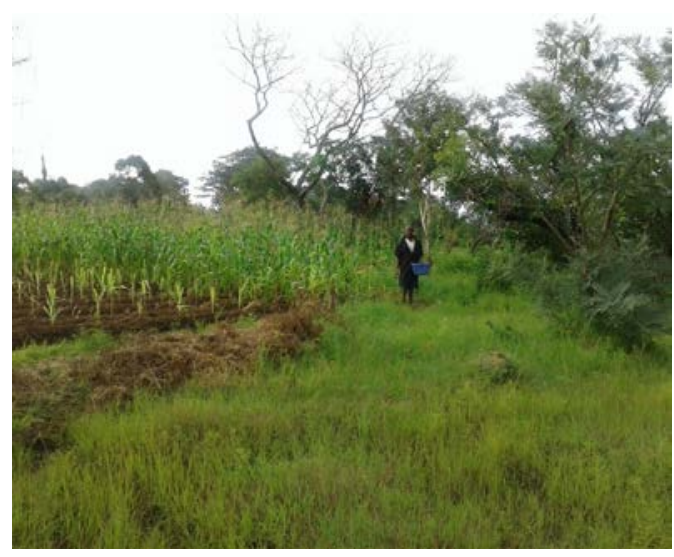

Figure 3. A Farmer and his farmland.

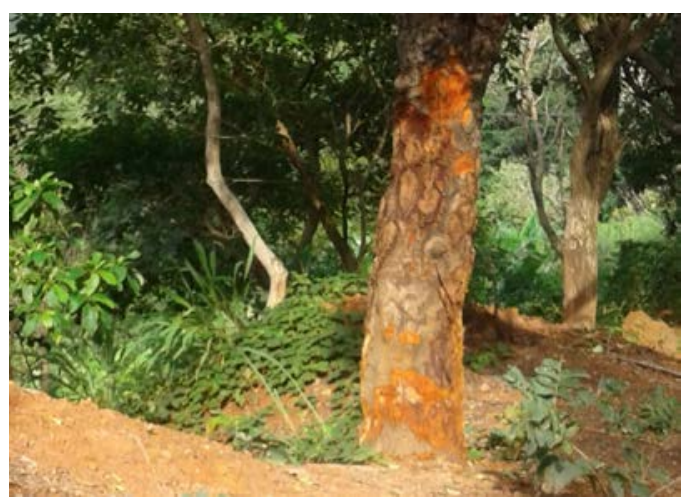

Figure 4. Debarked tree.

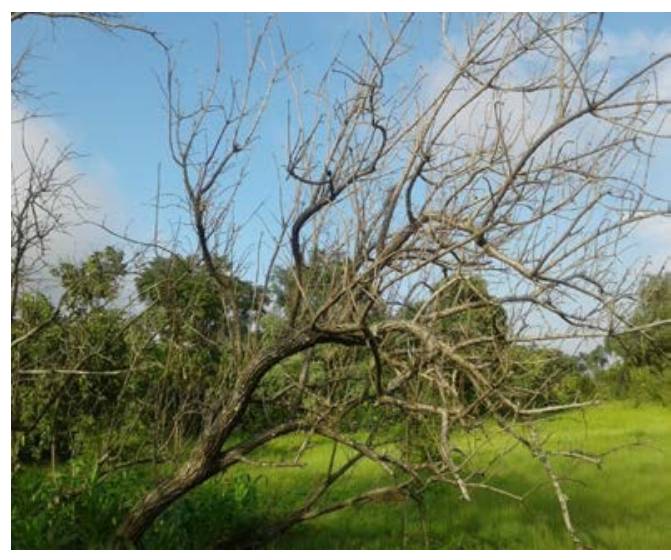

Figure 5. Saw dust, an indication of timber lumbering.

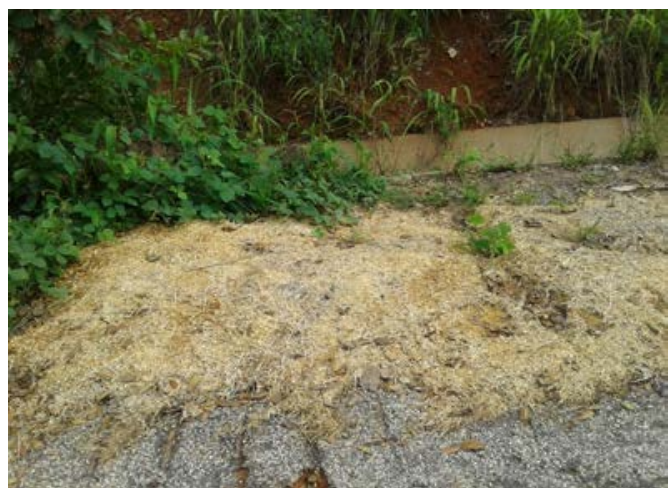

Figure 6. A dead tree caused by slash-and burn farming system. 
Table 2. Monthly encountered Rate of Bird Species from January to June 2018.

\begin{tabular}{|c|c|c|c|c|c|c|c|c|c|}
\hline Bird species & Jan & Feb & Mar & $\begin{array}{c}\text { Dry } \\
\text { season }\end{array}$ & Apr & May & Jun & $\begin{array}{c}\text { Wet } \\
\text { Season }\end{array}$ & $\begin{array}{l}\text { Grant } \\
\text { Total } \\
\end{array}$ \\
\hline Yellow-billed kite & 11 & 14 & 10 & 35 & 8 & 13 & 9 & 30 & 65 \\
\hline Stone partridge & 4 & 4 & 5 & 13 & 3 & 3 & 4 & 10 & 23 \\
\hline Red-eyed dove & 2 & 3 & 2 & 7 & 5 & 3 & 3 & 11 & 18 \\
\hline Mourning dove & 5 & 4 & 3 & 12 & 4 & 2 & 6 & 12 & 24 \\
\hline Laughing dove & 8 & 7 & 10 & 25 & 13 & 6 & 8 & 27 & 52 \\
\hline Black-billed wood dove & 3 & 5 & 2 & 10 & 4 & 4 & 4 & 12 & 22 \\
\hline Senegal coucal & 6 & 3 & 1 & 10 & 4 & 5 & 4 & 13 & 23 \\
\hline African grey hornbill & - & 4 & 2 & 6 & 1 & 4 & 6 & 11 & 17 \\
\hline Yellow-fronted tinkerbird & 4 & 3 & 4 & 11 & 6 & 5 & 6 & 17 & 28 \\
\hline Yellow-rumped tinkerbird & 2 & 2 & 6 & 10 & 7 & 4 & 8 & 19 & 29 \\
\hline Common bulbul & 8 & 5 & 6 & 19 & 7 & 5 & 7 & 19 & 38 \\
\hline Yellow-throated leaflove & - & - & - & $\mathbf{0}$ & 5 & 2 & 1 & 8 & 8 \\
\hline African thrush & 3 & 6 & 4 & 13 & 6 & 8 & 10 & 24 & 37 \\
\hline African paradise flycatcher & 2 & 1 & 5 & 8 & 3 & 4 & 4 & 11 & 19 \\
\hline Scarlet-chested sunbird & 3 & 6 & 4 & 13 & 5 & 8 & 6 & 19 & 32 \\
\hline Splendid sunbird & 5 & 6 & 8 & 19 & 6 & 4 & 6 & 16 & 35 \\
\hline Variable sunbird & 3 & 4 & 2 & 9 & 7 & 4 & 6 & 17 & 26 \\
\hline Copper sunbird & 3 & 4 & 4 & 11 & 7 & 3 & 4 & 14 & 25 \\
\hline Grey-headed sunbird & 2 & 2 & 6 & 10 & 4 & 3 & 4 & 11 & 21 \\
\hline African golden oriole & 4 & 2 & 6 & 12 & 3 & 2 & 3 & 8 & 20 \\
\hline Village weavers & - & - & - & $\mathbf{0}$ & 40 & 30 & 37 & 107 & 107 \\
\hline Little weaver & - & - & - & $\mathbf{0}$ & 8 & 6 & 10 & 24 & 24 \\
\hline Grey-backed camaroptera & 3 & 2 & 4 & 9 & 5 & 6 & 10 & 21 & 30 \\
\hline Black-crowned tchagra & 3 & 1 & 2 & 6 & 5 & 1 & 4 & 10 & 16 \\
\hline Pied crow & 5 & 7 & 4 & 16 & 3 & 5 & 3 & 11 & 27 \\
\hline Piapiac & 2 & 4 & 3 & 9 & 2 & 2 & 4 & 8 & 17 \\
\hline Red-cheeked cordon-blue & 3 & 6 & 7 & 16 & 4 & 7 & 5 & 16 & 32 \\
\hline Bronze mannikin & 5 & 7 & 10 & 22 & 15 & 11 & 13 & 39 & 61 \\
\hline Black-and-white mannikin & 5 & 4 & 6 & 15 & 13 & 9 & 9 & 31 & 46 \\
\hline Bare-breasted firefinch & 6 & 5 & 8 & 19 & 9 & 13 & 8 & 30 & 49 \\
\hline Swallows & 13 & 10 & 8 & 31 & 14 & 8 & 5 & 27 & 58 \\
\hline Green turaco & 1 & 3 & 1 & 5 & 3 & 2 & - & 5 & 10 \\
\hline Violet turaco & 5 & 4 & 3 & 12 & 4 & 3 & 3 & 10 & 22 \\
\hline African yellow white eye & - & - & 2 & 2 & 3 & 2 & 4 & 9 & 11 \\
\hline Yellow wagtail & - & - & 4 & 4 & 2 & 2 & - & 4 & 8 \\
\hline Western grey plantain-eater & 3 & 4 & 5 & 12 & 2 & 3 & 2 & 7 & 19 \\
\hline Yellow-throated long-claw & - & - & - & $\mathbf{0}$ & 4 & - & - & 4 & 4 \\
\hline Northern grey-headed sparrow & 2 & 3 & 4 & 9 & 2 & 5 & 3 & 10 & 19 \\
\hline Village indigo bird & 3 & 4 & 5 & 12 & 6 & 3 & 5 & 14 & 26 \\
\hline Total & 137 & 149 & 166 & 452 & 252 & 210 & 234 & 696 & 1,148 \\
\hline Shannon-Weiner Diversity & 5.24 & 3.28 & 3.39 & & 2.95 & 3.29 & 3.28 & & 3.41 \\
\hline Equitability & 1.51 & 0.93 & 0.95 & & 0.81 & 0.91 & 0.92 & & 0.93 \\
\hline
\end{tabular}




\section{Discussion}

The number of species encountered in this study revealed that the mountain is rich composition of bird species, even though the site seems to favour species that show preference to disturbed areas. The on-going anthropogenic activities probably paved way to these species to move in. Tanko (2012) reported how some species benefits from disturbance of a forest ecosystem, especially to opportunistic species. The encountered rate was high and is in agreement with the findings of (Burgess et al., 2002) that the tropical mountains serve as important bird area due to the high diversity of bird species including endemic species.

Monthly and seasonal fluctuation of bird species diversity and abundance may be due to a combination of physical and biological factors. Tanko et al. (2011) made a similar observation in their study. In attempting to advance reasons for the fluctuations, they assumed it could be due to accumulative effects of physical and biological factors of the habitat. The physical and biological factors observed at the site which we speculate could be reasons for the observed fluctuations include slash and burnt system of farming, fuel-wood harvesting, intensive sporting activities creation of foot paths etc. Creation of foot path alongside the farming activities brings about habitat fragmentation which may lead to decrease in patch colonization and increase in local extinction (Tanko et al., 2011). These factors have a combined effect of increase in human influx into the site. Human activities may interfere with breeding birds, disrupt mating individuals, and expose incubating birds to predators and also the destruction of nests and nestlings. Other possible factors that could be responsible for the fluctuations of the avifauna include seasonal nature of food sources where an increase in the abundance of macroinvertebrates and their larvae as well as fruits, seeds and nectar from plants in the wet season may lead to influx of insectivorous and fruigivorous birds (Tanko et al., 2011).

High encountered rate indicate abundance and high activity level of the species. However, Tanko et al. (2011) opined that there is a tendency to encounter more vocal and prominent species than the skulking and shy species. The village weaver was the most encountered species. This was probably because they are known to be lousy, move in flocks and breed in colonies. The vegetation and the interspersion of farmlands at the site also provided suitable nesting sites, nesting materials and foraging sites for the species.

The species effort curve indicated there are still more species to be discovered at the site. Tanko et al. (2012) recorded 107 species in a similar study in an inselberg in Zaria, Nigeria. The wet season had a higher abundance of encountered rate than the dry season. This supports the reports by Mengesha et al., (2008), in which they inferred that seasons and climate affect the composition and abundance of birds' species. The study also revealed three stenotopic species and goes to support the work of Tanko (2012) in which he reported that mountains may serve as source or sink for threatened, endemic and or stenotopic species.

It has been reported that in mountain ecosystems altitude affects birds' species composition, abundance and diversity (Hobson et al., 2003; Waterhouse et al., 2002). That was not observed in this study probably because the mountain is not high enough to bring about climatic and vegetational variations with altitude. As you go up a mountains there tends to be a decline in vegetation and elevation creates microclimate that in turn determines temperature, vegetation and soil characteristics. According to Rahbek (2005) these changes in altitude as you go up the mountain have effect on the distribution and diversity of bird species 
directly or indirectly through limiting the availability of their various needs and energy that flows into the ecosystem. This study however seemed to disagree with these findings as the study site revealed a uniform distribution of vegetation and hence had a uniform composition and abundance of birds both at lower and higher altitude.

Tanko (2012) in his work on Dumbi inselberg discovered more encountered rate in the dry season than the wet season and this he attributed to the presence of rock pools that serve as water source to the birds. However, this work is contrary to his findings and this is because the site is the only site with dense and thick vegetation that could serve as habitat for the birds and also provide fruits during the wet season.

\section{Conclusions}

The results showed rich composition and abundance of bird species on Mount Patti. The place is also home to stenotopic species as well as suitable breeding site for the weavers. We recommend further study of the sites as there are yet more species to be discovered. There is need for conservation procedures to be initiated at the place and this study should serve as a baseline to initiate such programme by the State Government.

\section{Conflict of interest}

Authors declare that they have no conflict of interests.

\section{References}

Adang, K. L.; Nsor, C.; Tela, M. Survey of avifauna of Gombe State University, Gombe, Nigeria. International Journal of Biology and Biological Sciences, v. 4, no. 2, p. 32-36, 2015.

Adang, K. L.; Tanko, D.; Kachi, J.; Abdulwahab, U. A. Bird species richness and diversity of Lokoja and Environs, Kogi State, Nigeria.
Proceedings of the 6th NSCB Biodiversity Conference,Uniuyo, p. 177-124, 2018.

Andren, H. Effects of habitat fragmentation on birds and mammals in landscapes with different proportions of suitable habitat: A review. Oikos, v. 71, p. 355-366, 1994.

Bascompte, J.; Jordano, P. Plant-animal mutualistic networks. The architecture of biodiversity. Annual Review of Ecology, Evolution, and Systematics, v. 38, p. 567593, 2007.

Benes, J.; Konvicka, M.; Storch, D.; Martinkova, J.; Gaston, J. Distribution pattern in butterflies and birds of the Czech Republic: Separating effects of habitat and geographical position. Journal of Biogeography, v. 30, p. 1195-1205, 2003.

Bibby, C.; Burgees, N.; Hill, D. Birds census techniques. London: Academic Press, 2000.

Bibby, J.; Burgress, N.; Hill, D. Bird census techniques. London: Academic Press, 1992.

BirdLife International. The threatened birds of the World. London: Lynx Editions, 2000

Birdlife International. Birds occur in all major habitat types, with forest being particularly important. 2008. Presented as Part of the Birdlife State of the World's Birds website. Available from: <http://www.birdlife.org/ datazone/sowb/casestudy/172>. Accessed on: March 7, 2018.

Buckley, H. L.; Freckleton, R.P. Understanding the role of species dynamics in abundance-occupancy relationships. Journal of Ecology, v. 98, p. 645-658, 2010.

Burgess, N. D.; Doggart, N.; Loveth, J. The Uluguru Mountains of Eastern Tanzania: The effect of forest loss on biodiversity. Oryx, v. 36, p. 140-152, 2002.

DeVault, T. L.; Brisbin, I. L.; Rhodes, O. E. Factors influencing the acquisition of rodent carion by vertebrate scavengers and decomposers. Canadian Journal of Zoology, v. 82, p. 502-509, 2004.

Fishpool, L. D. C.; Evans, M. I. Important birds areas and associated islands: Priority sites for. Newbury: Pisces Publications and Birdlife International, 2001. p. 673-696

Fuller, E. Extinct birds. 2. ed. Oxford: Oxford University Press, 2000. 
Gibbons, D. W. Birds. In: Sutherland, W. J. (Ed.). Ecological census tecniques. Cambridge: Cambridge University Press, 1996.

Godoy, J. A.; Jordano, P. Seed dispersal by animals: Exact identification of source trees with endocarp DNA microsatellites. Molecular Ecology, v. 10, p. 2275-2283, 2001. https://doi.org/10.1046/j.09621083.2001.01342.x

Harms, K. E.; Wright, S. J.; Calderon, O.; Hernandez, A.; Herre, E. A. Pervasive densitydependent recruitment enhances seedling diversity in a tropical forest. Nature, v. 404, p. 493-495, 2000. https://doi.org/10.1038/ 35006630

Hobson, K.; Wassenaar, L.; Mill, B.; Lovette, I.; Dingle, C.; Smith, T. Stable isotopes as indicators of altitudinal distribution and movement in an Ecuadorean Hummingbird Community. Oecology, v. 136, p. 302-308, 2003.

Jankowski, J.; Ciecka, A.; Meyer, N.; Rabenold, K. Beta diversity along environmental gradient: Implication of habitat specialization in tropical montane landscapes. Journal of Animal Ecology, v. 4, p. 315-327, 2009.

Judd, W. S.; Campbell, C. S.; Kellogg, E. A.; Stevens, A. F.; Donoghue, M. J. Plant systematics: Approach. 3. ed. Sunderland: Sinauer Associates, 2008.

Lozada, T.; Koning, G. H.; Marche, R.; Klein, A.M.; Tsharntke, T. Tree recovery and seed dispersal by birds: Comparing forest, agroforestry and abandoned agro-forestry in Coastal Ecuador. Perspectives in Plant Ecology, Evolution and Systematics, v. 8, no. 3, p. 131-140. 2007. https://doi.org/ 10.1016/j.ppees.2006.10.001

Manhães, M.; Ribeiro, A. Spatial Distribution and Diversity of Bird Community in an Urban Area of Southeast Brazil. Brazilian Archives of Biology and Technology, v. 48, no. 2, p. 285-294, 2005. https://doi.org/10.1590/ S1516-89132005000200016

Marzluff, J. M. Island biogeography for an urbanizing world: How extinction and colonization may determine biological diversity in human-dominated landscapes. Urban Ecosystems, v. 8, no. 2, p. 157-177, 2005. https://doi.org/10.1007/s11252-0054378-6
Mengesha, G.; Mamo, Y.; Bakele, A. A comparison of terrestrial bird community structure in the undisturbed and disturbed areas of the Abijata Shalla Lakes National Park, Ethipopia. International Journal of Biodiversity and Conservation, v.3, no. 9, p. 389-404, 2011.

Pain, D. J.; Cunningham, A. A.; Donald, P. F.; Duckworth, J. W.; Houston, D. C.; Katzner, T.; Parry-Jones, J., Poole, C.; Prakash, V.; Round, P.; Timmins, R. Causes and effects of temporospatial declines of Gyps vultures in Asia. Conservation Biology, v. 17, p. 661671, 2003.

Rahbek, C. The role of spatial scale and the perception of large-scale species-richness patterns. Ecology Letters, v. 8, no. 2, p. 224239, 2005. https://doi.org/10.1111/j.14610248.2004.00701.x

Shanahan, M.; Harrison, R. D.; Yamuna, R. Colonization of an island volcano, Long Island, Pua New Guinea and an emergent island, Motmot, in its caldera lake. V. Colonization by figs Ficus spp, their dispersers and pollinators. Journal of Biogeography, v. 28, p. 1365-1377, 2001. https://doi.org/10.1046/j.1365-2699.2001. 2811121365.x

Tanko, D. Some aspects of Ecology of the Dumbi Inselberg and its surrounding woodland in Zaria, Northern Nigeria. Ahmadu Bello: Department of Biological Sciences, Ahmadu Bello University, 2012. (PhD Dissertation).

Tanko D.; Ivande S. T. A survey of the avifauna of relatively undisturbed vegetation in Zaria, Nigeria. Roan: The Journal of Conservation, v. 5, no. 1, p. 131-140, 2011.

Tanko, D.; Adang, K. L.; Kachi J. B. Preliminary checklist of avifauna within Lokoja Metropolis, Kogi State, Nigeria. Inter. Jour.of Applied Biol. Res., v. 8, no. 2, p. 222-231, 2017.

Waterhouse, F.; Mather, M.; Seip, D. Distribution and abundance of birds relative to elevate on and biogeoclimatic zones in coastal old-growth forests in Southern British Columbia. B. C. Journal of Ecosystems and Management, v. 2, no. 2, p.1488-4674, 2002.

Wenny, D. G.; Levey, D. J. Directed seed dispersal by bellbirds in a tropical cloud forest. PNAS, v. 95, p. 6204-6207, 1998. https://doi.org/10.1073/pnas.95.11.6204 
Westphal, C.; Steffan-Dewenter; Tscharntke, T. Bumblebees experience landscapes at different spatial scales: Possible implication for coexistence. Oecologia, v. 149 , p. 289300, 2006.

(CC) License information: This is an open-access article distributed under the terms of the Creative Commons Attribution License, which permits unrestricted use, distribution, and reproduction in any medium, provided the original work is properly cited. 